\title{
Finding the Gap: Immigrant Integration Outcomes and Settlement Service Provision in the Republic of Ireland
}

\author{
Mary Gilmartin ${ }^{1}$ (D) Jennifer Dagg ${ }^{2}$ (B)
}

Accepted: 3 June 2021 / Published online: 5 July 2021

(C) The Author(s) 2021

\begin{abstract}
Immigrant integration is increasingly assessed through integration outcomes, which assess the degree of convergence of the experiences of immigrants and non-immigrants within a country. Integration processes - for example, settlement services in key areas such as employment, education and social inclusion - help to enhance integration outcomes. In this paper, we use the example of the Republic of Ireland to show that the relationship between desired integration outcomes and the provision of settlement services needs considerably more attention. We present immigrant integration outcomes for specific regions and groups of immigrants derived from existing largescale data sets. We then use publicly available data on existing settlement services to assess the extent to which settlement services address key areas of immigrant integration outcomes. We demonstrate that there are considerable gaps in the provision of appropriate settlement services that could support the enhancement of key integration outcomes, such as the quality of work, language proficiency and housing. If immigrant integration outcomes are to be improved, the relationship between outcomes and settlement service provision has to be better coordinated and targeted to address the structural barriers faced by particular groups of immigrants and by immigrants living in particular regions.
\end{abstract}

Keywords Immigrant integration · Integration outcomes $\cdot$ Settlement services $\cdot$ Ireland

Mary Gilmartin

mary.gilmartin@mu.ie

Jennifer Dagg

jenny.dagg@nuigalway.ie

1 Department of Geography, Maynooth University, Maynooth, Co Kildare, Ireland

2 Centre for Disability Law and Policy, Institute for Life Course and Society, NUI Galway, Galway, Ireland 


\section{Introduction}

In an extensive, and rapidly growing, literature on immigrant integration, there are three key areas of concern. The first is integration policies; the second is integration outcomes; and the third is integration processes. Each of these areas has garnered considerable attention. Immigrant integration policies are understood as "part of a normative political process in which the issue of integration is formulated as a problem, the problem is given a normative framing, and concrete policy measures are designed and implemented to achieve a desired outcome' (Penninx \& Garcés-Mascareñas, 2016, pp.19-20). That desired outcome is immigrant integration, the second area of concern. There is considerable disagreement over the meaning of immigrant integration. However, recent efforts to define and measure immigrant integration have focused on integration outcomes, by assessing the levels of economic and social convergence of the experiences of immigrants and non-immigrants, informed by the Zaragoza indicators (European Commission, 2010; Huddleston et al., 2013; OECD/European Union, $2015,2018)$. The third area of concern is integration processes. Here, the terminology is also unclear. For Penninx and Garcés-Mascareñes, integration is itself a process: they define it as 'the process of becoming an accepted part of society' (2016, p.14). In other contexts, such as Canada and Australia, the focus tends to be on the ways in which this process is supported through settlement (Squires, 2020). Settlement services, described as the support and assistance available to immigrants that help them become part of their new home (Shields et al., 2016, p.2), are an important aspect of this support. Given the lack of clarity, we find this focus on settlement services to be particularly useful in grounding the meaning of integration processes. These three areas of concern are important and interconnected aspects of immigrant integration: integration policies provide the context for integration processes, which in turn influence integration outcomes. Governments and government departments have considerable responsibility in relation to immigrant integration: they develop integration policies; they play a crucial role in assessing integration outcomes; and they are amongst the main funders and providers of settlement services.

In this paper, our aim is to investigate the convergence between the different domains of governmental responsibility for immigrant integration. We focus in particular on the Republic of Ireland, a relatively recent country of immigration. In doing so, we have two main goals. Firstly, we consider how the Irish government has measured and framed immigrant integration outcomes in the period since its first integration policy was published. Secondly, we assess the extent to which the provision and availability of settlement services in the Republic of Ireland is related to immigrant needs as demonstrated by these outcomes. In the next section, we provide background information on the Republic of Ireland and its experiences of immigration and integration over the past two decades, and we provide contextual information on the development of immigrant integration policy and the official measurement of immigrant integration outcomes. Following this, we discuss the provision of settlement services in the Republic of Ireland, with a focus on the role of the Irish government. In the next section, we consider the relationship between these settlement services and the official immigrant integration outcomes. We then discuss the connections and gaps between integration outcomes as measured by the Irish government, and the settlement services they provide - directly or indirectly - to immigrants. In the Discussion section that 
follows, we highlight the broader limitations in the provision of settlement services in Ireland, and the implications of this for successful immigrant integration. We conclude by calling for a more sustained attention, in countries of immigration, to the relationship between integration processes and integration outcomes.

\section{Ireland, Immigration and Integration Processes}

The Republic of Ireland is a useful setting to explore the relationship between immigrant integration outcomes and integration processes in the form of settlement services. This is for two key reasons. The first is the recent and rapid change to migration patterns in the Republic of Ireland. The second is the way in which the Irish government and civil society responded to these changes, informed in part by broader European debates and practices. Our focus on the Republic of Ireland thus offers insights into the role of governments in the process of integration in new immigration countries, in European countries and in countries experiencing social and economic challenges. In this section, we outline the significant changes to immigration flows and migrant stock in the Republic of Ireland since the late 1990s, and detail how immigrant integration policy and practice developed in response.

According to Census 1996, just $5.9 \%$ of the population was born outside the Republic of Ireland. Of these, over $71 \%$ were born in either England, Scotland or Wales (CSO, 1996), many to Irish parents and thus, automatically, Irish nationals. In 1996, therefore, immigrants had a limited presence in Ireland, and the immigrant population was relatively homogenous in its place of origin. Twenty years later, Census 2016 provided a very different picture. In this period, the population of the Republic of Ireland grew by $31 \%$ - from 3.6 million to 4.8 million (CSO 2016). This change was primarily due to the levels of immigration: the Central Statistics Office (CSO) estimates that around 1.4 million people immigrated to the Republic of Ireland in this 20-year period (CSO, 2020). Between 1996 and 2016, the population born outside the Republic of Ireland grew by $222 \%$, increasing from just over 251,000 in 1996 to over 810,000 in 2016-17.3\% of the total population (CSO, 1996, 2016). In addition to the growth in numbers, the places of birth had also diversified considerably. By 2016, just $27 \%$ of those born outside the Republic of Ireland had England, Scotland or Wales as a place of birth, with $28.4 \%$ born in EU-13 countries, $12.7 \%$ in Australasia and $6.3 \%$ in African countries (CSO, 2016). Routes of entry to the Republic of Ireland were varied. The majority of immigrants resident in the Republic of Ireland in 2016 were EU nationals, and thus needed no special permission to move to the country. Others moved to Ireland using different immigrant permissions, including student visas, employment visas, family reunification visas and as refugees or asylum seekers.

As the number of immigrants living in Ireland ${ }^{1}$ began to grow, Irish state and society started to pay more attention to the issue of immigrant integration. The first Minister for Integration was appointed in 2007, and the first significant policy document on integration, Migration Nation, was published in 2008 (Gilmartin, 2015; Office of the Minister for Integration, 2008). However, the 2008 economic crash in Ireland, followed by a sustained period of austerity, diverted government attention away from the issue of

\footnotetext{
${ }^{1}$ From this point onwards, we generally use the term 'Ireland' to refer to the Republic of Ireland.
} 
immigrant integration. The ministerial position was merged into other posts, before eventually being abolished in 2011. Migration Nation remained the only official government statement on immigrant integration. It was not updated, despite the rise and diversification of the immigrant population of the country. Eventually, in acknowledgement of this reality, the Irish government began to engage again with the issue of immigrant integration. The ministerial post with responsibility for immigrant integration was reinstated in 2016, and the second policy document on immigrant integration, The Migrant Integration Strategy, was published in 2017 (Department of Justice and Equality, 2017). In their assessment of integration policies across a range of countries, MIPEX ranked Ireland joint $14^{\text {th }}$ in 2007 , joint $16^{\text {th }}$ in 2011 and $19^{\text {th }}$ in 2014 (MIPEX, 2015). In 2014, the MIPEX commentary on Ireland was stark. They wrote:

Little has changed in the government's role and policies on integration, other than ad hoc projects, discussions and guidelines. National authorities are not doing much more than they did in 2007 (only +1 on MIPEX scale in 7 years) (MIPEX, 2015, p.133)

In the most recent MIPEX report, published in 2020, the assessment has changed. In 2020, Ireland's integration policies were ranked in the top ten, as one of the countries with a 'comprehensive approach to integration'. The assessment of Ireland, while noting on-going problems with labour market mobility, attributes this improvement to 'the focus provided by the 2017-2020 Migrant Integration Strategy' (MIPEX, 2020).

In addition to the recent developments in the domain of integration policy, the Irish government has also been involved in efforts to assess immigrant integration outcomes. In Ireland, the official assessment of integration outcomes provides data on a small number of quantitative measures, taken from the Zaragoza indicators. Since 2011, there have been seven reports on immigrant integration outcomes, all of which have been directly supported by the Irish government either through expertise, funding or both (Barrett et al., 2017; McGinnity et al., 2011, 2012, 2013, 2014, 2018, 2020). In total, 12 indicators have been assessed across all seven reports, relating to four of the five domains specified by the Zaragoza indicators: employment (3), education (2), social inclusion (4) and active citizenship (3). Details of the 12 indicators for 2011 and 2020, the first and most recent reports, are shown in Table 1. The Irish reports are similar to the broader OECD/European Union reports on immigrant integration, in that they focus on statistical indicators of the extent of 'economic and social convergence between immigrants and the native-born' (OECD/European Union, 2015, p.15). The foreword to the most recent report, written by the Minister with responsibility for integration, concluded that 'overall, migrants to Ireland are integrating well across the range of indicators examined' (McGinnity et al., 2020, p.1).

Compared to the EU average, it does appear that immigrant integration outcomes in Ireland are good. Looking at the 2020 figures in Ireland and the 2018 figures for the EU, immigrants in Ireland have higher levels of employment, higher household incomes, lower levels of unemployment and a lower at risk of poverty rate. However, comparing the outcomes for immigrants in Ireland with the outcomes for non-immigrants, some important differences emerge. The first is that immigrants have consistently higher levels of education and slightly higher employment rates. Despite this, immigrant households have a lower median net income, and this figure has increased 
Table 1 Immigrant integration outcomes in the Republic of Ireland, 2011, 2020 and in the EU, 2018

\begin{tabular}{|c|c|c|c|c|c|}
\hline \multirow[t]{2}{*}{ Outcome } & \multicolumn{2}{|l|}{2011} & \multicolumn{2}{|l|}{2020} & \multirow{2}{*}{$\begin{array}{l}\text { EU average, } \\
2018 \\
\text { Foreign-born }\end{array}$} \\
\hline & Irish & $\begin{array}{l}\mathrm{N} \text { o n - } \\
\text { Irish }\end{array}$ & Irish & $\begin{array}{l}\mathrm{N} \text { o n - } \\
\text { Irish }\end{array}$ & \\
\hline \multicolumn{6}{|l|}{ Employment (3) } \\
\hline Employment rate & $58.9 \%$ & $59 \%$ & $69 \%$ & $73 \%$ & $64 \%$ \\
\hline Unemployment rate & $13.8 \%$ & $18.2 \%$ & $5 \%$ & $6 \%$ & $12 \%$ \\
\hline Activity rate & $68.3 \%$ & $72.1 \%$ & $72 \%$ & $77 \%$ & \\
\hline \multicolumn{6}{|l|}{ Education (2) } \\
\hline Share of 25-34 age group with third-level education & $47 \%$ & $49 \%$ & $53 \%$ & $60 \%$ & $\mathrm{~N} / \mathrm{A}$ \\
\hline Share of early leavers from education & $9.4 \%$ & $10.4 \%$ & $4.3 \%$ & $3.7 \%$ & N/A \\
\hline \multicolumn{6}{|l|}{ Social inclusion (4) } \\
\hline Median net income & $€ 20,115$ & $€ 19,630$ & $€ 22,125$ & $€ 19,869$ & $€ 12,500$ \\
\hline At risk of poverty rate & $14.2 \%$ & $13.0 \%$ & $14.5 \%$ & $18.3 \%$ & $30 \%$ \\
\hline $\begin{array}{l}\text { Population share with self-perceived good or very } \\
\text { good health }\end{array}$ & $82.5 \%$ & $91.6 \%$ & $83.1 \%$ & $87.7 \%$ & $68 \%$ \\
\hline Proportion of property owners & $78.6 \%$ & $26.5 \%$ & $78.4 \%$ & $28.3 \%$ & N/A \\
\hline \multicolumn{6}{|l|}{ Active citizenship (3) } \\
\hline Share of immigrants that have acquired citizenship & & $16 \%$ & & $37.0 \%$ & N/A \\
\hline $\begin{array}{l}\text { Share of immigrants with permanent/long-term res- } \\
\text { idence permits }\end{array}$ & & $7 \%$ & & $0.7 \%$ & $\mathrm{~N} / \mathrm{A}$ \\
\hline $\begin{array}{l}\text { Share of immigrants amongst elected local } \\
\text { representatives }\end{array}$ & & $0.2 \%$ & & $0.7 \%$ & N/A \\
\hline
\end{tabular}

Sources: McGinnity et al., 2011; McGinnity et al., 2020; OECD/EU 2018

by only $1.2 \%$ between 2011 and 2020, compared to an increase of $10 \%$ for nonimmigrant households. Immigrants are also, in 2020, much more likely to be at risk of poverty than was the case in 2011 , and more likely to be at risk of poverty than nonimmigrants. There is also a stark difference in property ownership: just $28.3 \%$ of nonIrish residents were property owners in 2020 , compared to $78.4 \%$ of Irish. While some of the headline figures certainly suggest good integration outcomes for immigrants in Ireland, a closer look reveals obvious divergences in relation to social inclusion, and raises concerns about potential divergences in relation to employment.

However, the absences from the regular reports on immigrant integration outcomes in Ireland are also important. The OECD/EU reports, which include an assessment of integration outcomes in Ireland, make use of a broader range of measures, some of which show a less favourable picture of integration outcomes in Ireland. For example, the overqualification rate for immigrants in Ireland was $41 \%$ (compared to $29 \%$ for natives and the EU average for immigrants of 34\%). Four percent of immigrants lived in overcrowded accommodation (compared to $0 \%$ for natives). Other key measures that are proposed by the Zaragoza indicators, but not addressed in the Irish reports in a consistent manner, include language proficiency, quality of employment, public sector employment, membership of trade unions, or any of the indicators of a 'welcoming society'. The presentation of immigrant integration outcomes for all immigrants across 
the entire country, without spatial or social differentiation, also means that differences in integration outcomes between diverse immigrant groups or diverse regions are obscured. The exclusion of key measures from the monitoring of immigrant integration outcomes in Ireland means that the official reports provide an incomplete picture of 'successes and failures' (OECD/European Union, 2018), and raises questions about the Minister's statement that immigrants are 'integrating well'.

The general assessment of both integration policies and integration outcomes as positive has served to divert attention from the third aspect of the Irish government's role in promoting immigrant integration: the provision of settlement services. The experiences of 'settlement countries', where 'immigration is considered part of the national heritage' and the 'economic and social integration of immigrants ... is relatively successful' (OECD/European Union, 2018, p.27), show that the provision of appropriate settlement services is a crucial part of improving integration outcomes. Successful settlement services provide basic services on arrival, such as social welfare, health and safety. Following this, they seek to develop capacities, with a particular emphasis on human development (e.g. language training and education) and employment services, and to advocate for migrants (Garkisch et al., 2017). In settlement countries such as Canada and Australia, governments are actively involved in the provision of a wide range of settlement services, with some evidence that nongovernmental orgainsations [NGOs] are becoming more involved in service provision, particularly in areas of identified needs/service gaps (Kandasamy \& Soldatic, 2018; Richmond \& Shields, 2005; Shields et al., 2016). In contrast, the Irish government has paid limited attention to the provision of settlement services, emphasising instead a mainstreamed approach in line with many European countries (Scholten et al., 2017). The Irish government expressly states that its reports on immigrant integration outcomes suffice as an assessment of the settlement services it provides (Office for the Promotion of Migrant Integration, 2019, p.34). In the next section, we discuss the provision of settlement services in Ireland, and show how our research project sought to map the current landscape of settlement service provision in order to enhance understanding of this third aspect of the Irish government's role in immigrant integration.

\section{Settlement Services in the Republic of Ireland}

To date, broader academic and policy research on settlement services in the Republic of Ireland has focused on two key aspects: the provision of services; and the services provided to one group of immigrants, those seeking international protection. In relation to the provision of services, there has been a particular emphasis on the role of NGOs. Cullen details the broader context for the relationship between the Irish government and civil society under a governance model called 'social partnership'. Under this model, the Irish NGO sector 'entered into agreements to provide services to the state in exchange for access to funding opportunities and participation in episodic corporatist policy deliberations' (2009, p.111). Rather than the Irish state becoming directly involved in the provision of settlement services, these were instead mostly devolved to majority-led NGOs or framed as a matter of individual responsibility (Cullen, 2009, p.124). Gray described the specific role of the Catholic Church in the provision of settlement services in Ireland, seeing it as connected to a broader European-wide 
phenomenon where states roll back service provision, and instead contract this out to a variety of organisations, including faith-based organisations (Gray, 2013, p.74). While migrant-led groups have been emerging in Ireland, they face particular difficulties in becoming involved in settlement service provision. As Ejorh suggests, many lack 'proper organisational structures, recognition and the capacity for growth and development' (Ejorh, 2015, p.680), and often struggle with a lack or loss of funding (Lentin, 2012, p.197). Overall, then, research and commentary have focused on civil society involvement in the provision of settlement services, and there have been limited efforts to map the role of the Irish government in this enterprise.

The most sustained interest has been in the settlement services provided to refugees and, to a lesser extent, asylum seekers. Ireland admits and/or recognises a small number of people as refugees each year. The settlement services provided to refugees - often described as 'integration supports' - are well documented and analysed. O'Neill (2001) provides an overview of the support for programme refugees admitted to Ireland between 1994 and 2000, noting the important role of the Refugee Agency (O'Neill, 2001, p.95). After Ireland introduced its Direct Provision scheme for asylum seekers in 2000, the Refugee Agency was merged into a new Reception and Integration Agency (RIA), under the control of the Department of Justice, in early 2001, though as Kinlen points out, "the "integration" element of the unit ...was confined to Convention and Resettled refugees' (2011, p.36), and was later moved to the Office for the Promotion of Migrant Integration (OPMI). Kinlen (2011) provides a detailed account of the 'stark differences' (2011, p.38) in the treatment and services offered to refugees and asylum seekers. As an example, resettled refugees received orientation, integration support and free language training. None of these settlement services were available to asylum seekers (2011, p.41). These differences have persisted, with Arnold et al. (2019, p.12) recently observing that resettled refugees benefit 'from a more formalised and targeted system of supports, including orientation' than spontaneous refugees (asylum seekers). The limited support available to asylum seekers in particular has been receiving considerable critical attention (Nedeljkovic, 2018; Ní Raghallaigh \& Thornton, 2017; O'Reilly, 2018; White, 2012).

In summary, existing research on settlement services in Ireland emphasises the role of NGOs and the provision of services to a specific migrant group, and there is no overarching account of settlement services. In our broader research project, we sought to address this gap in knowledge. The project was funded by the Irish Research Council, and carried out between 2017 and 2018, following ethical approval from the Maynooth University Social Research Ethics Subcommittee. One of its key goals was to map the network of existing settlement services in Ireland, and we charted the provision and availability of settlement services for immigrants in Ireland using a range of methods. Firstly, we identified the specific public or other bodies who were identified as having responsibility for specific aspects of immigrant integration. We also sought to identify the sources of funding that were available for the provision of settlement services. Next, we searched for available information about existing settlement services. We did this by exploring websites, social media and other publicly available information to draft an initial list of settlement services: in doing so, our aim was to see what information on services would be easily available to an individual looking for support. We held three workshops in December 2017 where we presented our initial list of settlement services to civil society organisations and service providers. 
Following feedback, we further refined our understanding of settlement services in the Republic of Ireland. In the next section, we chart how the Irish government allocates responsibility and funding for settlement service provision.

\section{The Role of the Irish Government in the Provision of Settlement Services}

The Migrant Integration Strategy expressly states that immigrant integration issues are to be mainstreamed into the general work of government departments (Department of Justice and Equality, 2017, p.4). This follows the trend across a range of European countries. Scholten et al. define mainstreaming as 'a process towards generic and polycentric policies' (Scholten et al., 2017, p.290), and suggest that mainstreaming is being used more often in relation to immigrant integration. Their review of policies in France, Germany, Denmark and the UK concluded that these now generally 'address the entire population rather than specific migrant, ethnic or racial groups' (Scholten et al., 2017, p.297), though there is some evidence of new area-based approaches, often targeting specific urban areas with high residential concentrations of immigrants. In Ireland, there is less evidence of the development of substantial area-based approaches, but the strategy does provide clear evidence of an ideological commitment to mainstreaming.

For the purposes of this paper, it is important to consider how the strategy frames the expected role of the Irish state in the provision of settlement services. Specifically, the strategy highlights 12 categories of action in relation to migrant integration, and expressly mentions the bodies with responsibility for specific actions. In Table 2, we detail these categories and responsibilities. We also indicate how these categories are related - if at all - to the Zaragoza immigrant integration outcomes.

As Table 2 shows, actions that are included in the Zaragoza Active Citizenship indicators receive considerable attention in this strategy, including access to citizenship, political participation and volunteering. While government departments are considered to have responsibility for all of these actions, a broader range of groups are designated as having responsibility for encouraging political participation. Involvement in sport is not specifically listed in the Zaragoza indicators, but it is possible to consider this action also as a form of active citizenship. In contrast, Education and Employment - both considered highly significant for successful integration - each represent just one action. The strategy provides more specific measures under each of actions. For Education, there are 12 listed measures. Of these, 9 relate to the education of migrant children in schools and at third level. Just 3 relate to English language proficiency, 2 of which clearly indicate that this is an individual responsibility. For Employment, there are 10 listed measures. Four relate to migrant unemployment, 3 relate to the broader issue of representativeness in public sector employment and on State boards, 2 are concerned with the recognition or development of skills and 1 with encouraging migrant entrepreneurs. The particular emphasis on those who are unemployed is again clear evidence of mainstreaming, given the broader implementation of a work-first activation policy in Ireland from 2011 onwards (Murphy, 2016). There are few specific actions in relation to Social Inclusion, other than a commitment to monitoring poverty and social exclusion amongst migrants, and to research on how mainstream services are meeting the needs of immigrants. Across the range of actions, the main government department-allocated responsibilities are Education and Skills; Social Protection; 
Table 2 Immigrant integration actions and responsible body/bodies in the Republic of Ireland, 2017

\begin{tabular}{|c|c|c|c|c|c|c|c|}
\hline \multirow[t]{3}{*}{ Category of action } & \multirow{3}{*}{$\begin{array}{l}\text { Number } \\
\text { of measures }\end{array}$} & \multirow{3}{*}{$\begin{array}{l}\text { Related } \\
\text { Zaragoza } \\
\text { indicator }\end{array}$} & \multicolumn{5}{|c|}{ Responsible body/bodies } \\
\hline & & & \multirow[t]{2}{*}{$\begin{array}{l}\text { Government } \\
\text { departments }\end{array}$} & \multirow[t]{2}{*}{ OPMI } & \multirow[t]{2}{*}{$\begin{array}{l}\text { Local } \\
\text { authorities }\end{array}$} & \multicolumn{2}{|c|}{$\begin{array}{l}\text { Third Sector } \\
\text { Organisations } \\
\text { [TSOs] }\end{array}$} \\
\hline & & & & & & NGOs & Other \\
\hline General & 8 & All & $\checkmark$ & $\checkmark$ & & & \\
\hline Education & 12 & Education & $\checkmark$ & & & & $\checkmark$ \\
\hline $\begin{array}{l}\text { Employment and } \\
\text { pathways to work }\end{array}$ & 10 & Employment & $\checkmark$ & & & & $\checkmark$ \\
\hline $\begin{array}{l}\text { Access to public services } \\
\text { and social inclusion }\end{array}$ & 11 & $\begin{array}{l}\text { Social } \\
\text { inclusion }\end{array}$ & $\checkmark$ & $\checkmark$ & $\checkmark$ & & \\
\hline Health & 3 & $\begin{array}{l}\text { Social } \\
\text { inclusion }\end{array}$ & & & & & $\checkmark$ \\
\hline $\begin{array}{l}\text { Access to citizenship/long } \\
\text { term residency }\end{array}$ & 6 & Active & & & & & \\
\hline citizenship & $\checkmark$ & & & & & & \\
\hline Political participation & 3 & Active & & & & & \\
\hline citizenship & $\checkmark$ & & $\checkmark$ & $\checkmark$ & $\checkmark$ & & \\
\hline Volunteering & 1 & Active & & & & & \\
\hline citizenship & $\checkmark$ & & & & & & \\
\hline $\begin{array}{l}\text { Promoting intercultural } \\
\text { awareness and combating } \\
\text { racism and xenophobia }\end{array}$ & 11 & $\begin{array}{l}\text { Welcoming } \\
\text { Society }\end{array}$ & $\checkmark$ & $\checkmark$ & $\checkmark$ & & $\checkmark$ \\
\hline $\begin{array}{l}\text { Integration in the } \\
\text { community }\end{array}$ & 7 & $\mathrm{n} / \mathrm{a}$ & $\checkmark$ & $\checkmark$ & $\checkmark$ & & \\
\hline Sport & 1 & $\mathrm{n} / \mathrm{a}$ & & $\checkmark$ & & & $\checkmark$ \\
\hline $\begin{array}{l}\text { Implementation and } \\
\text { follow-up }\end{array}$ & 3 & $\mathrm{n} / \mathrm{a}$ & $\checkmark$ & $\checkmark$ & & & \\
\hline
\end{tabular}

Source: Department of Justice and Equality, 2017, pp.21-35

Housing, Planning, Community and Local Government; Justice and Equality; and Jobs, Enterprise and Innovation. The Office for the Promotion of Migrant Integration is also regularly listed as having responsibility for actions, together with a wide range of public bodies, including local authorities.

In addition to the range of actions specified in the strategy, the Office for the Promotion of Migrant Integration provides details of a range of funding schemes designed to support immigrant integration. These are listed in Table 3. Of these five schemes, just one - the Communities Integration Fund - is opened on an annual basis.

The Communities Integration Fund offers grants of up to $€ 5,000$ to community organisations to support integration in their local areas. Just over $€ 1.5$ million was dispersed to community organisations over the 3-year period from 2017 to 2019 . The grants are usually one-off awards: over the 3-year period, only around $20 \%$ of organisations received more than 1 grant. Awardees include sports clubs, family centres and small migrant-led organisations. 
Table 3 Funding to support immigrant integration in the Republic of Ireland

\begin{tabular}{|c|c|c|c|c|}
\hline Scheme & Funder & Focus & $\begin{array}{l}\text { Award } \\
\text { dates }\end{array}$ & $\begin{array}{l}\text { Total } \\
\text { amount } \\
\text { awarded } \\
€ \text { million }\end{array}$ \\
\hline $\begin{array}{l}\text { Asylum Migration and } \\
\text { Integration Fund (AMIF) }\end{array}$ & European Union & $\begin{array}{l}\text { Refugee resettlement; EU } \\
\text { relocation; Integration }\end{array}$ & 2016 & 2019 \\
\hline \multicolumn{5}{|l|}{9.0} \\
\hline $\begin{array}{l}\text { European Social Fund } \\
\text { - Programme for } \\
\text { Employability, Inclusion } \\
\text { and Learning (PEIL) }\end{array}$ & European Union & $\begin{array}{l}\text { Migrant Integration; Migrant } \\
\text { Employment }\end{array}$ & 2016 & 3.3 \\
\hline $\begin{array}{l}\text { National Funding } \\
\text { Programme }\end{array}$ & $\begin{array}{l}\text { Office for the } \\
\text { Promotion of } \\
\text { Migrant } \\
\text { Integration }\end{array}$ & Migrant Integration & 2017 & 1.9 \\
\hline $\begin{array}{l}\text { Communities Integration } \\
\text { Fund }\end{array}$ & $\begin{array}{l}\text { Office for the } \\
\text { Promotion of } \\
\text { Migrant } \\
\text { Integration }\end{array}$ & Community projects & 2017 & $\begin{array}{l}2018 \\
2019\end{array}$ \\
\hline \multicolumn{5}{|l|}{1.5} \\
\hline Dormant Accounts Funds & $\begin{array}{l}\text { Dormant Accounts } \\
\text { Funds, } \\
\text { administered by } \\
\text { Pobal }\end{array}$ & $\begin{array}{l}\text { Labour market integration of female } \\
\text { refugees and female family } \\
\text { members of refugees }\end{array}$ & 2017 & 0.5 \\
\hline
\end{tabular}

Sources: Department of Justice and Equality, 2020a, 2020b, 2020c; European Social Fund in Ireland, 2020

The National Funding Programme has operated once, in 2017. In that year, it committed to funding 15 projects, each for a 3 -year period. Of these projects, only 5 have a nationwide scope, though often targeting a small group of people, e.g. migrant teachers, primary school teachers and young people. Just one of the 15 projects has no restrictions on participation: Fáilte Isteach, a volunteer English language training programme (Department of Justice and Equality, 2020b). Similarly, the Dormant Accounts Fund has been directed towards integration once, also in 2017, when it was used to provide 7 projects with support for 1 year (Department of Justice and Equality, 2020c). The remaining schemes are both funded by the European Union and administered by OPMI. PEIL funding for immigrant integration was last awarded in 2016, when 5 projects each received funding for 4 years (European Social Fund in Ireland, 2020). AMIF funding was awarded to 20 organisations in 2016 and to 19 organisations in 2019 - this is for substantial schemes where the minimum award is $€ 150,000$, and so awardees include well-established migrant-focused NGOs and local development companies (Department of Justice and Equality, 2020a). A significant proportion of funds is allocated to NGOs, and many of the funded programmes target specific groups of migrants, for example refugees, asylum seekers, third country nationals, women or young people. There is no evidence of funding being allocated to government departments for the purposes of mainstreaming. Across the five funding schemes, there is considerable overlap between many of the proposed projects, and the links between the proposed projects and mainstreamed public services is not always apparent. 
We also sought to identify settlement services that targeted four of the Zaragoza domains - employment, education, social inclusion and active citizenship - and their providers (either the Irish government or Third Sector Organisations [TSOs]). TSOs were active in all four domains, while the Irish government had some role in providing settlement services related to employment, education and social inclusion. The Irish government provides general settlement services to migrants through its Citizens Information Services. These services provide information on employment, education and social inclusion online, by phone and through drop-in centres (O'Connor, 2017). The services are explicit about their role in supporting migrants: they use the terms 'clients and callers' to identify people using their services, and describe users as 'Irish citizens or people from other countries living in Ireland' (O'Connor, 2017, p.4). Annual reports suggest that close to a quarter of clients are immigrants whose queries are often related to employment rights (O'Sullivan \& Hartigan, 2011). Mainstreamed employment services for immigrants are directed towards those who are unemployed, and emphasise activation (Murphy, 2016). The Irish government also provides some mainstreamed support for social inclusion through Local Authorities and SICAP (the social inclusion and community activation programme). However, local authorities in Ireland have a limited range of functions compared to their European counterparts: their role has been described as 'services to property or infrastructure-type services, as opposed to services to people' (Turley et al., 2018, p.471). Given this, their main role in relation to immigrant integration is through the provision of social housing. In general, though, settlement services in the domains of employment, education and active citizenship are provided by a range of TSOs. These include migrant focused NGOs, migrant and/or community led organisations, and organisations such as Education and Training Boards (ETBs), Local Development Companies (LDCs), and Family Resource Centres. ETBs are public bodies with a statutory education function: they are funded by the state and through fees paid by individuals for courses. In contrast, both LDCs and Family Resource centres are locally based organisations that receive state funding, though this funding was cut significantly under austerity (Meade, 2018). Our review of settlement services thus identified some mainstreaming, but more evidence of services provided by a wide range of third sector organisations, many with limited, short-term and/or insecure sources of funding.

\section{Integration Outcomes and Settlement Services in Ireland: Analysing the Connections and the Gaps}

In this section of the paper, we analyse the connections between integration outcomes as measured by the Irish government, and the settlement services they provide directly or indirectly - to immigrants. In doing so, our particular interest is in identifying the extent to which the settlement services provided are targeted to areas of need that are evident in the quantitative measurement of integration outcomes. While evaluating the success of these settlement services in improving integration outcomes is important in the longer term, this paper asks if 10 years of integration outcome monitoring in Ireland has resulted in the development of appropriate settlement services? In doing this, we are assessing the claim of the Irish government that 'comparing migrant outcomes against outcomes for the native population ... provides insight on 
how mainstream services are meeting migrant needs and whether there are areas that require additional focus' (Office for the Promotion of Migrant Integration, 2019, p.34). In other words, are those areas being given additional focus?

The combination of immigrant integration outcomes shown in Table 1 and produced by the OECD suggests that, for immigrants as a whole, domains that require additional focus include employment and social inclusion. In the second component of our research project, we investigated immigrant integration outcomes further, seeking to expand the range of indicators and to consider whether or not there were differences in outcomes in different regions of the country and for different broad migrant groups. In doing so, we used data that is publicly available and would have been available to the authors of the monitoring report. This included data from existing large-scale statefunded data sets, such as the Census, the Survey of Income and Living Conditions and the Labour Force Survey. In some instances, this information was immediately available through a public website; in other instances, we requested special tabulations of data from the Central Statistics Office in Ireland, the public body responsible for data collection. Table 4 provides an overview of additional immigrant integration outcomes for Irish nationals as a whole, and for two different immigrant groups and regions ${ }^{2}$.

Table 4, based on data that has already been gathered by the Irish government, provides additional insights into the more general measures of immigrant integration outcomes provided by the monitoring reports. In particular, it raises questions about the extent to which it is possible to say that immigrants are 'integrating well'? This table indicates clear areas of concern. This includes underemployment, language proficiency and postgraduate education for immigrants from the EU-13 and for immigrants living in the Border region; high levels of unemployment and high poverty risk rates for immigrants from outside the EU and for immigrants living in the Border region; and very low levels of home ownership for all immigrants, particularly those living in the Dublin region. This table also shows that it is difficult for immigrants to gain employment in public administration, and that levels of trade union membership are low for immigrants, particularly those with an EU-13 nationality. In our investigation of settlement service availability, we paid particular attention to these key areas. We looked at the services that were available to help improve employment, education and social inclusion integration outcomes, and we considered the extent to which these services were targeted to address the specific issues that are apparent amongst particular groups or within particular regions.

However, our review of settlement services showed few if any attempts to systematically address these issues. In relation to employment, the State provides mainstreamed services for people who are unemployed, often associated with ensuring their return to employment under a broader work-first approach (Murphy, 2016). In general, though, these services are subcontracted to a wide range of third sector organisations and, increasingly, private companies. The specific focus is on ensuring people's participation in the workforce. From an integration perspective, this funding often targets specific groups of migrants, e.g. refugees, people with leave to remain, or

\footnotetext{
${ }^{2}$ In our broader research project, we focused on two immigrant groups: EU-13 nationals (Bulgaria, Croatia, Cyprus, Czech Republic, Estonia, Hungary, Latvia, Lithuania, Malta, Poland, Romania, Slovakia, Slovenia) and Non-EU nationals. We also focused on two of the eight NUTS 3 regions in Ireland - Dublin and the Border region - because of their different socio-economic and immigrant profile. See Gilmartin and Dagg $(2018,2021)$ for more information.
} 
Table 4 Additional key integration outcome indicators for the Republic of Ireland (2016-2018)

\begin{tabular}{|c|c|c|c|c|c|c|c|c|}
\hline \multirow[t]{3}{*}{ Domain } & \multirow[t]{3}{*}{ Indicator } & \multicolumn{3}{|c|}{ Nationality } & \multicolumn{4}{|l|}{ Region } \\
\hline & & \multirow[t]{2}{*}{ Irish } & \multirow[t]{2}{*}{ EU-13 } & \multirow[t]{2}{*}{ Non-EU } & \multicolumn{2}{|l|}{ Dublin } & \multicolumn{2}{|l|}{ Border } \\
\hline & & & & & Irish & $\begin{array}{l}\text { Non- } \\
\text { Irish }\end{array}$ & Irish & $\begin{array}{l}\text { Non- } \\
\text { Irish }\end{array}$ \\
\hline \multirow[t]{4}{*}{ Employment } & Unemployment rate & $12.5 \%$ & $14.2 \%$ & $21.5 \%$ & $11.6 \%$ & $11.6 \%$ & $15.0 \%$ & $20.5 \%$ \\
\hline & Underemployed & $2 \%$ & $4.5 \%$ & $2.4 \%$ & $\mathrm{~N} / \mathrm{a}$ & $\mathrm{N} / \mathrm{a}$ & $\mathrm{N} / \mathrm{a}$ & $\mathrm{N} / \mathrm{a}$ \\
\hline & $\begin{array}{l}\text { Employed in public } \\
\text { administration }\end{array}$ & $5.4 \%$ & $0.4 \%$ a & $0.7 \%$ & $5.8 \%$ & $1.2 \%$ & $5.5 \%$ & $1.2 \%$ \\
\hline & $\begin{array}{l}\text { Employed in } \\
\text { accommodation } \\
\text { and food services }\end{array}$ & $3.9 \%$ & $12.8 \% \mathrm{a}$ & $14.3 \%$ & $4.7 \%$ & $10.6 \%$ & $3.3 \%$ & $11.3 \%$ \\
\hline \multirow[t]{2}{*}{ Education } & $\begin{array}{l}\text { Completed } \\
\text { postgraduate } \\
\text { education }\end{array}$ & $8.1 \%$ & $6.7 \%$ & $13.6 \%$ & $11.9 \%$ & $13.0 \%$ & $5.8 \%$ & $5.9 \%$ \\
\hline & $\begin{array}{l}\text { No or limited ability } \\
\text { to speak English }\end{array}$ & $\mathrm{n} / \mathrm{a}$ & $19.9 \%$ a & $15.4 \%$ & $\mathrm{n} / \mathrm{a}$ & $18.9 \%$ & $\mathrm{n} / \mathrm{a}$ & $11.9 \%$ \\
\hline \multirow{3}{*}{$\begin{array}{l}\text { Social } \\
\text { inclusion }\end{array}$} & At risk of poverty rate & $16.5 \%{ }^{\mathrm{b}}$ & $15.8 \%$ & $42.0 \%$ & $11 \%$ & $19 \%$ & $23 \%$ & $27 \%$ \\
\hline & $\begin{array}{l}\text { Household net income - } \\
\text { median }\end{array}$ & $\mathrm{n} / \mathrm{a}$ & $€ 42,018$ & $€ 37,600$ & $€ 57,793$ & $€ 48,639$ & $€ 39,052$ & $€ 36,751$ \\
\hline & Owns own home & $76.8 \%$ & $10.6 \%$ & $15.0 \%$ & $68.0 \%$ & $18.5 \%$ & $76.5 \%$ & $33.6 \%$ \\
\hline $\begin{array}{l}\text { Active } \\
\quad \text { citizenship }\end{array}$ & $\begin{array}{l}\text { Trade union } \\
\text { membership }\end{array}$ & $9.4 \%$ & $4.2 \%$ & $2.8 \%$ & $\mathrm{n} / \mathrm{a}$ & $\mathrm{n} / \mathrm{a}$ & $\mathrm{n} / \mathrm{a}$ & $\mathrm{n} / \mathrm{a}$ \\
\hline
\end{tabular}

Notes

a Includes Polish, Lithuanian, Latvian and Romanian only

$\mathrm{b}$ This is the figure for the state as a whole, including both Irish and non-Irish nationals. This data was not made available for Irish nationals at the level of the state

Sources: CSO (2016); Gilmartin and Dagg (2018, 2021); McGinnity et al. (2018)

migrant women. However, a recent evaluation of the SICAP pre-employment supports indicated difficulties in involving such groups who face significant barriers, particularly in rural areas (Whelan et al., 2020, p.ii). The broader issues our review of integration outcomes identified - specifically, underemployment and sectoral concentration - are not targeted by the settlement services provided. It is clear from the data in Table 4 that there are high levels of underemployment amongst EU-13 migrants in particular. It is also clear that both EU-13 and non-EU immigrants are concentrated in sectors of employment with poor wages and conditions (e.g. accommodation and food services), while struggling to access sectors of employment with better wages and conditions (e.g. public administration). The differences in levels of trade union membership provide further evidence that the quality of employment available to EU-13 immigrants in particular is poor. These established patterns of sectoral concentration and underemployment, based on existing data, have been acknowledged by academic and civil society researchers previously (see, for example, Gilmartin, 2013, 2014, based on 2011 Census data). Despite this, there is no evidence of settlement services directed towards improving the quality of work available to immigrants, in either a general or a targeted 
manner. Instead, the goal is any kind of work: the nature of that work, and its suitability given the training and skills of individual workers, is not considered a priority. This approach serves to perpetuate patterns of immigrant underemployment, exacerbates the process of deskilling, and works to individualise responsibility for improving the quality of work, regardless of the structural barriers that make this difficult. The proportion of immigrants employed in public administration is a clear example of these structural barriers in practice.

The second important dimension is education. Here, we pay particular attention to the levels of proficiency in the English language. Language proficiency is an important attribute: it enhances people's employment opportunities; it makes accessing services easier; and it helps with everyday communication and the development of relationships. The Migrant Integration Strategy and its predecessor, Migration Nation, both highlighted the significance of language proficiency. Most recently, the 2017 Strategy stated 'certain issues still create barriers to integration. These include language acquisition, particularly for those recently arrived in Ireland' (Department of Justice and Equality, 2017, p.7), and the strategy outlined a range of measures to address this, including adult English language courses (2017, pp.25-27). Earlier, Migration Nation appeared to commit to the development of a national English language training programme (Office of the Minister for Integration, 2008, p.63). However, there has been limited progress in this regard. When we considered integration outcomes for immigrants by nationality and by region, we found evidence that immigrants from EU13 countries, and immigrants living in the Border region, had lower levels of selfreported English language proficiency than immigrants from outside the EU or immigrants living in the Dublin region. Despite this, we found no evidence of a systematic approach to language training, particularly in the Border region or for EU-13 migrants. Instead, an ad hoc approach to language training exists, often through TSOs such as NGOs or ETBs, but without necessarily responding to specific local needs. For example, the NGO Fáilte Isteach provides free English language classes to migrants, mostly provided by older volunteers. However, it has limited capacity in the Border region both in terms of venues and times. Participants in workshops highlighted examples of alternative approaches to language acquisition, such as ETB-provided classes funded by employers. As Prendergast shows, though, this is rare, with many employers saying they could not afford to provide English language classes for employees. Instead, employees argue that language acquisition should be a governmental responsibility, and funded by the Department of Education and Skills. The Minister for Integration disagreed, placing the responsibility for English language acquisition on employers and employees (Prendergast, 2016, p.457). A consequence is that despite its acknowledged importance, limited English language proficiency remains an issue in particular regions and for particular groups, and there is no clear response in terms of the targeted provision of settlement services.

The third important dimension is social inclusion. Our review of integration outcomes suggested that there are two important dimensions of social inclusion for specific migrant groups and regions: levels of income/poverty, and housing. Clearly, underemployment and sectoral concentration contribute to a person's capacity for earning a decent wage and/or their risk of poverty. When people are unemployed or underemployed, the state also provides income and other supports. In most cases, these supports are mainstreamed. However, service providers have identified significant 
difficulties for migrants who are trying to access these supports, particularly where they have limited English language proficiency. For example, while the Department of Social Protection and Employment Affairs - responsible for administering many of these supports - is in theory committed to providing interpretive and translation services on request, in practice there is a 'gap in the awareness of, and access to, interpreter services by customers with language support needs' (Crosscare, 2018, p.6). As a consequence, there are concerns that 'people who should be entitled to payments are not getting them or are struggling to do so' (Crosscare, 2018, p.40), thus exacerbating their risk of poverty. The second is housing. Immigrant integration outcome measures show a stark difference in the housing situation of immigrants in general, with particularly marked differences in the Dublin region. Specifically, immigrants are considerably more likely to be living in rental accommodation than their nonimmigrant counterparts. In the Dublin region, immigrants are also less likely to be living in social housing. The housing crisis in Ireland, centred on cities like Dublin, has made rental accommodation more difficult to access and considerably less affordable, and tenants in Ireland have considerably less protection than in many other European countries. In their report for the Department of Justice, Fahey et al. described the Irish housing market as 'dysfunctional', with immigrants facing problems with affordability, security of tenure and discrimination (Fahey et al., 2019, p.68). Yet, the state provides very limited support to immigrants in relation to housing, beyond the mainstreamed welfare rent supplement payment and the mainstreamed social housing list. While some TSOs provide support to tenants, there are no targeted supports to deal with the specific difficulties immigrants face in relation to access to affordable and secure housing. Housing is a key component of integration in general, and recognised as such in Canada, where the range of housing settlement services available to immigrants includes assistance in finding temporary and permanent housing and access to housing that is only available to new immigrants (Praznik \& Shields, 2018, p.9). In contrast, the issue of housing is not mentioned in the Irish government's integration strategy, and is not central to state or TSO settlement service provision.

In these three important domains of immigrant integration - employment, education and social inclusion - we identified a disjuncture between the issues highlighted by the measurement of immigrant integration outcomes in Ireland, and the settlement services offered to immigrants. We discuss this disjuncture, and its broader implications for immigrant integration, in the next section.

\section{Discussion: Immigrant Integration Outcomes and Settlement Services - Learning from Disjunctures}

Overall, we uncovered three broad limitations in the provision of settlement services in Ireland: funding and provision; availability and access; and fit. In relation to funding and provision, there is limited evidence that the specific needs of particular groups of immigrants are addressed through the mainstreamed provision of services. This mirrors the findings of a related study of Irish public sector integration policies, which found that 'there have been very limited efforts to develop appropriate immigrant integration policies in public bodies' (Murphy et al., 2019, p.41). Instead, services are generally provided by a wide range of TSOs, including a number of migrant-focused NGOs, and 
by some private companies. Many of these TSOs are partially or wholly funded by the state, through funding mechanisms that are short-term and competitive. This approach to funding means that public bodies are not developing expertise in settlement service provision, and that TSOs struggle to sustain the consistent provision of settlement services over the medium to longer term. The second issue is availability and access. Settlement services availability is spatially uneven. The larger NGOs are generally based in urban areas, with fewer and smaller organisations in more rural areas such as the Border region. Given the importance of NGOs in particular to settlement service provision, this imbalance means that immigrants living outside the main urban centres have fewer options in relation to directed support. While there is a network of local authorities to cover all areas, we found that they did not have a consistent approach to the issue of immigrant integration. Some local authorities were pro-active, but others showed little initiative in developing integration processes. Often, successful integration initiatives were highly dependent on a small number of motivated people: if those people did not have permanent positions, or moved to other jobs, the efforts directed towards developing integration processes dissipated. There are also difficulties in relation to access, as many settlement services are targeted towards specific groups of immigrants, for example refugees. Other groups of immigrants, for example international students from outside the EU, are explicitly prohibited from accessing mainstreamed services (Gilmartin et al., 2020). We found evidence that, occasionally, settlement service providers were providing informal access to people who did not meet the criteria. However, this was done through personal initiative and was not publicised, in order to ensure that services appeared to be provided only as mandated. The third issue is fit. This is particularly important, as it addresses whether or not settlement services in Ireland are related to immigrant needs as demonstrated by immigrant integration outcomes. Our assessment is that there is no explicit link between integration outcomes and settlement services in general, or for particular groups or regions. Some of the key dimensions to immigrant integration, such as quality of employment, housing or language skills, were inadequately or not addressed in the provision of targeted settlement services. Employment-related settlement services, in particular, are directed towards immigrants who are unemployed, and so are rarely available to immigrants who are experiencing underemployment or deskilling. The focus instead was on other dimensions of immigrant integration, such as active citizenship. This served to direct attention to the actions or behaviour of individual immigrants rather than identifying and/or mitigating structures of exclusion.

Assessed on its own terms, the provision of settlement services to immigrants in Ireland follows similar trends to other countries. The first is a commitment to mainstreaming, which is now increasingly common (Galandini et al., 2019; Scholten et al., 2017). The second is the role of third sector organisations in the provision of targeted settlement services (Kandasamy \& Soldatic, 2018; Mayblin \& James, 2019). The third is the increasing role of private companies, particularly in relation to employment-focused services (Collins \& Murphy, 2016; Shields et al., 2016). However, there are also some important differences or divergences. While the Irish state has a discursive commitment to mainstreaming, our and other research highlight the limitations of this commitment in practice, whether through the lack of development of immigrant integration policies (Murphy et al., 2019) or the failure to provide adequate support to immigrants using public services (Crosscare, 2018). The commitment to 
mainstreaming in a range of European countries has resulted in the growing importance of the local level of governance for immigrant integration (Scholten et al., 2017, p.298). In Ireland, the restrictions on the role of local government mean that few local authorities have become actively involved in settlement service provision, beyond a small number who have actively sought short-term funding for specific and timelimited projects. Instead, TSOs are more active locally though, particularly in areas outside cities, their ability to become involved in service provision faces resource, staffing and expertise restrictions. And while TSOs provide immigrant settlement services in a range of countries, they play a particularly important role in Ireland because of the country's long history of subcontracting social service provision, initially to the Catholic Church and, more recently, to church-initiated pro-migrant NGOs (Cullen, 2009; Gray, 2013).

However, when the provision of settlement services in Ireland is assessed in relation to immigrant integration outcomes, considerable barriers to successful integration become evident. There is no clear link between the integration outcomes that are considered significant and the services that are provided to support the process of integration. This serves to individualise immigrant integration, since the Irish government does not take direct or indirect responsibility for supporting better integration outcomes through the provision of appropriate settlement services. Instead, immigrants have to be personally responsible for developing their language skills, improving their employment situation, or enhancing their housing situation, often at significant personal cost. There is a stated commitment to mainstreaming, which again serves to individualise responsibility. However, the failure to develop effective mainstreaming again means that individual immigrants who struggle to access services are constructed as the problem, rather than the system itself. Finally, funding for settlement services is temporary, ad hoc and often competitive, so it is difficult for the main service providers - third sector organisations - to develop and sustain expertise and to provide consistent services. As a consequence, from our perspective the reality of settlement services, in many cases, undermines the possibility of improved immigrant integration outcomes.

\section{Conclusion}

Our research shows the importance of investigating all domains of government responsibility for immigrant integration. In addition to measuring immigrant integration outcomes in a more complete and nuanced way, this also requires a more sustained attention to the process of integration, as evident through settlement services. Our analysis of integration outcomes and settlement service provision in Ireland raises a number of significant issues in relation to the role of governments in immigrant integration. Taken at face value, immigrant integration in Ireland is well supported by appropriate policy development, with integration outcomes that appear favourable. Given the positive assessment of policy (by MIPEX) and outcomes (by the Minister with responsibility for integration, based on state-gathered data), the implication is that the process of immigrant integration in Ireland is progressing well. However, this is not the full story. We argue that the measurement of immigrant integration outcomes is incomplete, and that the relationship between integration outcomes and settlement services is fragmented at best. The lack of a systematic and synthetic approach to 
settlement services means that the Irish government has not given sufficient attention to the process of integration, with the result that structural barriers to immigrant integration are not being identified or addressed.

States like Ireland regularly profess their commitment to immigrant integration. The Migrant Integration Strategy expressly states that its goal is to ensure that 'barriers to [immigrant] integration are identified and removed' (Department of Justice and Equality, 2017, p.3). Our research shows that potential barriers to immigrant integration include the lack of recognition of the relationship between integration processes and integration outcomes, and the lack of coordination to ensure that settlement services address the structural barriers faced by particular groups of immigrants and by immigrants living in particular regions. If these barriers are to be addressed, the relationship between integration outcomes and settlement services has to be at the heart of integration policy and practice. Successful immigrant integration requires appropriate integration policies, sufficient monitoring of immigrant integration outcomes, and a commitment to enhance outcomes through the provision of targeted settlement services. Our research shows that settlement services need to be adequately funded, address identified needs and need to be spatially and socially accessible. Without this level of attention to the process of integration, governments are not providing sufficient support to enhance both immigrant integration and societal cohesion, a pressing issue in a time of increasing social unrest across a range of European societies.

Acknowledgements The authors would like to acknowledge the support of the Irish Research Council; the research assistance of Rhonda McGovern, Mireia Guardino Ferran, Jennifer White and Matt Stephens; workshop participants who shared their knowledge and expertise with us; support from the Maynooth University Department of Geography and Maynooth University Social Sciences Institute, particularly Professor Gerry Kearns, Professor Linda Connolly and Neasa Hogan; and encouragement provided by the Maynooth Geography Writing Group.

Author Contribution Mary Gilmartin developed the initial study conception and design and applied for funding. Both authors refined the design of the study as it progressed. Material preparation, data collection and analysis were performed by Jennifer Dagg and Mary Gilmartin. The first draft of the manuscript was written by Mary Gilmartin and both authors commented on the previous versions of the manuscript. Both authors read and approved the final manuscript.

Funding Open Access funding provided by the IReL Consortium. Research for this paper was funded by the Irish Research Council under its Research for Policy and Society Scheme, and was carried out as part of a broader study entitled 'Mapping processes of integration and settlement in contemporary Ireland', conducted between 2017 and 2018.

Data availability Not applicable

Code Availability (Software Application or Custom Code) Not applicable.

\section{Declarations}

Conflicts of Interest/Competing Interests The authors declare no competing interests. 
Open Access This article is licensed under a Creative Commons Attribution 4.0 International License, which permits use, sharing, adaptation, distribution and reproduction in any medium or format, as long as you give appropriate credit to the original author(s) and the source, provide a link to the Creative Commons licence, and indicate if changes were made. The images or other third party material in this article are included in the article's Creative Commons licence, unless indicated otherwise in a credit line to the material. If material is not included in the article's Creative Commons licence and your intended use is not permitted by statutory regulation or exceeds the permitted use, you will need to obtain permission directly from the copyright holder. To view a copy of this licence, visit http://creativecommons.org/licenses/by/4.0/.

\section{References}

Arnold, S., Quinn, E., Gusciute, E., \& Kinlen, L. (2019). Cultivating problems for the future: integration supports for resettled and spontaneous refugees in Ireland. Migration Studies. https://doi.org/10.1093/ migration/mnz016.

Barrett, A., McGinnity, F., \& Quinn, E. (Eds.). (2017). Monitoring Report on Integration 2016. ESRI/ Department of Justice and Equality.

Collins, M. L., \& Murphy, M. P. (2016). Activation: Solving Unemployment or Supporting a Low-Pay Economy? In M. Murphy \& F. Dukelow F. (Eds.), The Irish Welfare State in the Twenty-First Century. Palgrave Macmillan. https://doi.org/10.1057/978-1-137-57138-0_4.

Crosscare (2018). Do You Speak English? A Study on Access to Interpreter Services in Public Social Welfare Offices in Ireland. https://www.migrantproject.ie/wp-content/uploads/2018/12/Do-You-Speak-English.A-Study-on-Access-to-Public-Social-Welfare-Offices-in-Ireland.-Crosscare.2018.pdf. Accessed 30 Jul 2020.

CSO (1996). Table A0427: 1996 Population Usually Resident in the State by Birthplace, County of Usual Residence, Sex and Census Year. https://statbank.cso.ie/px/pxeirestat/statire/SelectTable/Omrade0.asp? PLanguage $=0$. Accessed 30 Jul 2020.

CSO (2016). 2016 Census Results. Tables EA004, EB005, EB035, EY001, E7054, E7062. https://statbank. cso.ie/px/pxeirestat/statire/SelectTable/Omrade0.asp?Planguage=0. Accessed 30 Jul, 19 Aug 2020.

CSO (2020). Table PEA15: Annual Population Change by Component and Year. https://statbank.cso.ie/px/ pxeirestat/statire/SelectTable/Omrade0.asp?PLanguage=0. Accessed $30 \mathrm{Jul} 2020$.

Cullen, P. (2009). Irish pro-migrant nongovernmental organizations and the politics of immigration. Voluntas, 20, 99-128. https://doi.org/10.1007/as11266-009-9084-1.

Department of Justice and Equality (2017). The Migrant Integration Strategy: A Blueprint for the Future. Dublin. http://www.justice.ie/en/JELR/Migrant_Integration_Strategy_English.pdf/Files/Migrant Integration_Strategy_English.pdf. Accessed 30 July 2020.

Department of Justice and Equality (2020a). 2019 AMIF Open Call (AMIF). at http://eufunding.justice.ie/en/ eufunding/pages/2019-amif-open-call-amif. Accessed 30 July 2020.

Department of Justice and Equality (2020b). OPMI National Funding Programme. http://www.integration.ie/ en/isec/pages/wp18000023. Accessed 30 July 2020.

Department of Justice and Equality (2020c). Dormant Accounts Funded Projects. http://www.integration.ie/ en/isec/pages/wp18000025. Accessed 30 July 2020.

Ejorh, T. (2015). The challenge of resilience: migrant-led organisations and the recession in Ireland. Journal of International Migration and Integration, 16, 679-699.

European Commission (2010). Declaration of the European Ministerial Conference on Integration. https:/ec. europa.eu/migrant-integration/librarydoc/declaration-of-the-european-ministerial-conference-onintegration-zaragoza-15-16-april-2010. Accessed 26 August 2020.

European Social Fund in Ireland (2020). Integration and Employment of Migrants. https:/www.esf.ie/en/ about-us/what-do-we-fund-/integration-and-employment-of-migrants/integration-and-employment-ofmigrants.html. Accessed 15 July 2020.

Fahey, É., Russell, H., McGinnity, F., \& Grotti, R. (2019). Diverse Neighbourhoods: An Analysis of the Residential Distribution of Immigrants in Ireland. ESRI/ Department of Justice and Equality.

Galandini, S., Mulvey, G., \& Lessard-Phillips, L. (2019). Stuck between mainstreaming and localism: views on the practice of migrant integration in a devolved policy framework. Journal of International Migration and Integration, 20, 685-702. https://doi.org/10.1007/s12134-018-0626-5. 
Garkisch, M., Heidingsfelder, J., \& Beckmann, M. (2017). Third sector organizations and migration: a systematic literature review on the contribution of third sector organizations in view of flight, migration and refugee crises. Voluntas, 28, 1839-1880. https://doi.org/10.1007/s11266-017-9895-4.

Gilmartin, M. (2013). Changing Ireland, 2000-2012: immigration, emigration and inequality. Irish Geography, 46(1-2), 91-111. https://doi.org/10.1080/00750778.2013.794323.

Gilmartin, M. (2014). Immigration and Spatial Justice in Contemporary Ireland. In G. Kearns, D. Meredith, \& J. Morrissey (Eds.), Spatial Justice and the Irish Crisis (pp. 161-176). Royal Irish Academy.

Gilmartin, M. (2015). Diversity in Crisis: Reshaping Contemporary Ireland. In T. Matejskova \& M. Antonsich (Eds.), Governing Through Diversity (pp. 61-79). Palgrave Macmillan.

Gilmartin, M., \& Dagg, J. (2018). Immigrant Integration and Settlement Services in Ireland. MUSSI https:// www.maynoothuniversity.ie/sites/default/files/assets/document//Immigrant\%20Integration\%20Final\% 20Report\%202018\%20\%28002\%29.pdf.

Gilmartin, M., \& Dagg, J. (2021). Spatializing immigrant integration outcomes. Population, Space and Place, 27(2), e2390. https://doi.org/10.1002/psp.2390.

Gilmartin, M., Rojas Coppari, P., \& Phelan, D. (2020). Promising precarity: the lives of Dublin's international students. Journal of Ethnic and Migration Studies, 1-18. https://doi.org/10.1080/1369183X.2020. 1732617.

Gray, B. (2013). Migrant Integration and the 'Network-Making Power' of the Irish Catholic Church. In M. Gilmartin \& A. White (Eds.), Migrations: Ireland in a Global World (pp. 55-79). Manchester University Press.

Huddleston, T., Niessen, J., \& Dag Tjaden, J. (2013). Using EU Indicators of Immigrant Integration (Final Report for DG of Home Affairs). Publications Office of the European Union.

Kandasamy, N., \& Soldatic, K. (2018). Implications for practice: exploring the impacts of government contracts on refugee settlement services in rural and urban Australia. Australian Social Work, 71(1), 111-119. https://doi.org/10.1080/0312407X.2017.1357079.

Kinlen, L. (2011). Welcome to Ireland: seeking protection as an asylum seeker or through resettlement different avenues, different reception. Refuge, 28(2), 31-47.

Lentin, R. (2012). Conclusion: Integration from Below? In R. Lentin \& E. Moreo (Eds.), Migrant Activism and Integration from Below in Ireland (pp. 182-200). Palgrave Macmillan.

Mayblin, L., \& James, P. (2019). Asylum and refugee support in the UK: civil society filling the gaps? Journal of Ethnic and Migration Studies, 45(3), 375-394. https://doi.org/10.1080/1369183X.2018.1466695.

McGinnity, F., Quinn, E., O’Connell, P., \& Donnelly, N. (2011). Annual Monitoring Report on Integration 2010. ESRI and The Integration Centre.

McGinnity, F., Quinn, E., Kingston, G., \& O’Connell, P. (2012). Annual Monitoring Report on Integration 2011. ESRI and The Integration Centre.

McGinnity, F., Quinn, E., Kingston, G., \& O’Connell, P. (2013). Annual Monitoring Report on Integration 2012. ESRI and The Integration Centre.

McGinnity, F., Quinn, E., Kingston, G., \& O’Connell, P. (2014). Annual Monitoring Report on Integration 2013. ESRI and The Integration Centre.

McGinnity, F., Fahey, É., Quinn, E., Arnold, S., Maître, B., \& O’Connell, P. (2018). Monitoring Report on Integration 2018. ESRI/Department of Justice and Equality.

McGinnity, F., Enright, S., Quinn, E., Maître, B., Privalko, I., Darmody, M., \& Polakowski, M. (2020). Monitoring Report on Integration 2020. ESRI/Department of Justice and Equality.

Meade, R. R. (2018). The re-signification of state-funded community development in Ireland: a problem of austerity and neoliberal government. Critical Social Policy, 38(2), 222-243. https://doi.org/10.1177/ 0261018317701611.

MIPEX (2015). Migrant Integration Policy Index 2015. http://2015.mipex.eu/. Accessed 16 March 2021.

MIPEX (2020). Migrant Integration Policy Index 2020: Ireland. https://www.mipex.eu/ireland. Accessed 16 March 2021.

Murphy, M. P. (2016). Low road or high road? The post-crisis trajectory of Irish activation. Critical Social Policy, 36(3), 432-452.

Murphy, C., Caulfield, L., \& Gilmartin, M. (2019). Developing immigrant integration policy in the Irish public sector: an international human rights and public sector duty approach. Administration, 67(4), $27-45$.

Nedeljkovic, V. (2018). Reiterating Asylum Archive: documenting direct provision in Ireland. Research in Drama Education: The Journal of Applied Theatre and Performance, 23(2), 289-293. https://doi.org/10. 1080/13569783.2018.1440202.

Ní Raghallaigh, M., \& Thornton, L. (2017). Vulnerable childhood, vulnerable adulthood: direct provision as aftercare for aged-out separated children seeking asylum in Ireland. Critical Social Policy, 37(3), 386404. https://doi.org/10.1177/0261018317691897. 
O'Connor, N. (2017). Making An Impact: The Public Value of Citizens Information Services in Ireland. Citizens Information Board https://www.citizensinformationboard.ie/downloads/social_policy/CIS_ Making_an_Impact_2017.pdf. Accessed 30 July 2020.

O’Neill, J. (2001). Integration of Refugees in Ireland: Experience with Programme Refugees 1994-2000. In C. Harvey \& M. Ward (Eds.), No Welcome Here? Asylum Seekers and Refugees in Ireland and Britain (pp. 94-101). Democratic Dialogue https://cain.ulster.ac.uk/dd/report14/ddreport14.pdf. Accessed 30 July 2020.

O'Reilly, Z. (2018). 'Living Liminality': everyday experiences of asylum seekers in the 'Direct Provision' system in Ireland. Gender, Place and Culture, 25(6), 821-842. https://doi.org/10.1080/0966369X.2018. 1473345.

O’Sullivan, M., \& Hartigan, C. (2011). The citizens information services in Ireland: protecting the nonunionized employee? Journal of Workplace Rights, 15(1), 65-82.

OECD/European Union. (2015). Indicators of Immigrant Integration 2015: Settling In. OECD Publishing.

OECD/European Union. (2018). Settling In 2018: Indicators of Immigrant Integration. OECD Publishing and European Union.

Office for the Promotion of Migrant Integration (2019) The Migrant Integration Strategy 2017-2020: Progress Report to Government. http://www.justice.ie/en/JELR/Pages/PB19000173. Accessed 2 March 2021.

Office of the Minister for Integration. (2008). Migration Nation. Office of the Minister for Integration.

Penninx, R., \& Garcés-Mascareñas, B. (2016). The Concept of Integration as an Analytical Tool and as a Policy Concept. In B. Garcés-Mascareñas \& R. Penninx (Eds.), Integration Processes and Policies in Europe: Contexts, Levels and Actors (pp.11-29). Springer.

Praznik, J., \& Shields, J. (2018). An anatomy of settlement services in Canada: a guide. A Paper of the Building Migrant Resilience in Cities (BMRC) Project. York University https://bmrc-irmu.info.yorku.ca/. Accessed 30 July 2020.

Prendergast, M. (2016). Training and developing non-Irish workers: the perspectives of interested stakeholders. European Journal of Training and Development, 40(6), 446-467.

Richmond, T., \& Shields, J. (2005). NGO-government relations and immigrant services: contradictions and challenges. Journal of International Migration and Integration, 6(3-4), 513-526.

Scholten, P., Collett, E., \& Petrovic, M. (2017). Mainstreaming migrant integration? A critical analysis of a new trend in integration governance. International Review of Administrative Sciences, 83(2), 283-302.

Shields, J., Drolet, J., \& Valenzuela, K. (2016) Immigrant Settlement and Integration Services and the Role of Nonprofit Service Providers: A Cross-national Perspective on Trends, Issues and Evidence. RCIS Working Paper No. 2016/1. Toronto: Ryerson Centre for Immigration and Settlement. https:/www. ryerson.ca/centre-for-immigration-and-settlement/publications/working-papers/. Accessed 28 July 2020.

Squires, P. (2020). A scoping review of Australian studies of refugee integration: popular definitions of integration in the Australian literature. Migration Studies, 8(1), 90-112.

Turley, G., McDonagh, J., McNena, S., \& Grzedzinski, A. (2018). Optimum territorial reforms in local government: an empirical analysis of scale economies in Ireland. The Economic and Social Review, 49(4), 463-488.

Whelan, A., Delaney, J., McGuinness, S, \& Smyth, E. (2020). Evaluation of SICAP Pre-employment supports. Economic and Social Research Institute. Research Series 109. 10.26504/rs109. Accessed 12 March 2021.

White, A. (2012). 'Every Wednesday I Am Happy': childhoods in an Irish asylum centre. Population, Space and Place, 18(3), 314-326. https://doi.org/10.1002/psp.659.

Publisher's Note Springer Nature remains neutral with regard to jurisdictional claims in published maps and institutional affiliations. 